\title{
Analisis konten pada buku paket matematika siswa SMP menggunakan kriteria Bell
}

\author{
Dila Nur Wahidah, Ida Nuraida dan Nunung Sobarningsih \\ Pendidikan Matematika, Tarbiyah dan Keguruan, UIN Sunan Gunung Djati Bandung, \\ Jl. A.H. Nasution No. 105 Cibiru, Kota Bandung \\ *idanuraida@uinsgd.ac.id
}

Received: 10 Januari 2021; Accepted: 11 Juni 2021; Published: 30 Juni 2021

\begin{abstract}
Abstrak
Tujuan penelitian ini untuk mengetahui hasil analisis konten pada buku paket matematika siswa edisi Kurikulum 2013 Revisi 2016 terbitan Kemendikbud dengan menggunakan Kriteria Bell. Metode penelitian ini adalah deskriptif kualitatif dengan subjek penelitiannya adalah buku paket matematika siswa SMP edisi Kurikulum 2013 Revisi 2016 terbitan Kemendikbud. Instrumen penelitian berupa lembar analisis kesesuaian buku. Pengambilan data berdasarkan hasil analisis yang dilakukan peneliti terhadap buku paket matematika siswa Sekolah Menengah Pertama edisi Kurikulum 2013 Revisi 2016 terbitan Kemendikbud berdasarkan konten kriteria Bell. Berdasarkan analisisnya, kesesuaian buku paket matematika terbitan Kemendikbud dilihat dari konten kriteria Bell mencapai 74, 29\% yang termasuk pada kategori baik.
\end{abstract}

Kata kunci: Analisis, Konten dan Kriteria Bell

\begin{abstract}
The purpose of this study was to find out the results of content analysis in students' mathematics textbooks in the 2013 Revised 2016 Curriculum edition published by the Ministry of Education and Culture using the Bell criteria. This research method is descriptive qualitative with the research subject is the mathematics textbook for junior high school students in the 2013 Revised 2016 Curriculum edition published by the Ministry of Education and Culture. The research instrument was in the form of a book suitability analysis sheet. Data collection was based on the results of an analysis conducted by researchers on the mathematics textbooks for junior high school students in the 2013 Revised 2016 Curriculum edition published by the Ministry of Education and Culture based on the content of Bell's criteria. Based on his analysis, seen from the content of Bell's criteria reached $74.29 \%$ which was included in the good category.
\end{abstract}

Keywords: Analysis, Content and Bell's Criteria 
Dila Nur Wahidah, Nunung Sobarningsih

Ida Nuraida

\section{PENDAHULUAN}

Dalam dunia pendidikan, kurikulum merupakan salah satu bagian yang tak kalah pentingnya. Sebab pada setiap jenjang pendidikan, kurikulum dijadikan sebagai acuan atau pengatur pada setiap jalannya proses belajar mengajar, hal tersebut guna memperbaiki pendidikan di Indonesia. Oleh karenanya, kurikulum dapat dipahami sebagai segala sesuatu atau segala aktivitas yang dilakukan peserta didik dan guru di sekolah untuk mencapai suatu tujuan tertentu.

Terbentuknya Kurikulum 2013 karena ada bagian perbaikan daripada Kurikulum Berbasis Kompetensi (Kurikulum 2004/KBK) dan Kurikulum Tingkat Satuan Pendidikan (Kurikulum 2006/KTSP). Dengan adanya perubahan kurikulum tersebut, maka berpengaruh pula kepada setiap mata pelajaran pada satuan pendidikan, termasuk pada mata pelajaran matematika. Kurikulum 2013 menyajikan mata pelajaran matematika dengan memulai topik-topik permasalahan yang nyata, yang umunya dijumpai pada lingkungan sekitar yang kemudian menjadi abstrak. Hal tersebut tentu dimaksudkan agar Indonesia mampu membentuk manusia yang dapat berpikir secara kreatif, produktif, inovatif, proaktif dan afektif, yang mana hal tersebut sesuai dengan tema pada pembaruan dan perbaikan daripada Kurikulum 2013.

Salah satu bentuk upaya Kurikulum 2013 mewujudkan perubahan tersebut adalah dengan menekankan proses pembelajaran menggunakan pendekatan scientific, yang mana pendekatan scientific ini menjadikan peserta didik sebagai pusat pembelajaran. Selain itu, upaya Kurikulum 2013 yang lain adalah dengan menghadirkan buku guru dan buku siswa yang pihak pemerintah telah fasilitasi sebagai buku wajib yang menjadi sumber belajar pada satuan pendidikan. Selaras dengan hal tersebut, dikutip dari ungkapan Azizah (2015: 3) bahwa dengan diterbitkannya dua jenis buku yakni buku guru dan buku siswa oleh pemerintah menjadi salah satu sarana yang mendukung implementasi Kurikulum 2013.

Buku siswa diartikan sebagai sebuah penjabaran usaha selama proses pembelajaran, baik yang dilakukan di dalam kelas maupun di luar kelas yang harus dicapai oleh peserta didik. Hal tersebut sejalan dengan yang diungkapkan oleh Shield \& Dole (2013sis: 183-199) bahwa selama proses pembelajaran berlangsung baik itu dilakukan di dalam kelas maupun di luar kelas, buku teks merupakan salah satu upaya untuk membangun pemahaman peserta didik terhadap tiap mata pelajaran termasuk mata pelajaran matematika.

Selain hal tersebut, untuk membantu mempermudah proses pembelajaran yang salah satunya berupa bahan pembelajaran cetak, buku siswa tentunya disusun berdasarkan sistematika yang sesuai dengan Kurikulum 2013. Dalam hal ini, buku siswa yang dimaksud ialah buku teks atau yang sering disebut dengan buku paket, yang mana buku paket merupakan kumpulan kertas yang dijilid menggunakan sampul berupa kertas tebal.

Kenyataan di lapangan menunjukkan bahwa tidak semua buku teks memiliki kelayakan isi dan kualitas yang maksimal meskipun buku teks dijadikan sebagai alat rujukan guru dan peserta didik dalam mengarahkan proses pembelajaran. Hasil observasi yang peneliti lakukan pada beberapa sekolah melalui wawancara kepada guru matematika, menunjukkan bahwa buku matematika siswa SMP/MTs yang diterbitkan oleh Kemendikbud khusunya pada penggunaan kosa kata yang digunakannya dirasa sulit dipahami baik itu oleh peserta didik maupun guru itu sendiri, atau dengan kata lain berbelit-belit. Selain itu, guru merasa bahwa materi yang disajikan belum lengkap, sehingga guru harus mencari referensi lain untuk melengkapi kekurangan materi yang tersajikan pada buku paket tersebut. Maka dari hal tersebut, secara singkat dinilai bahwa buku paket matematika siswa SMP/MTs yang diterbitkan oleh Kemendikbud yang digunakan belumlah sempurna. 
Ungkapan tersebut sejalan dengan yang dikemukakan oleh Ikhwandi et al. (2015: 118) meskipun buku paket menjadi rujukan untuk mengarahkan jalannya dari proses belajar mengajar, akan tetapi peran seorang guru harus mampu memilah dan mimilih dengan tepat buku paket yang menjadi rujukannya pada proses belajar mengajar, karena pada kenyataannya tidak semua buku paket memiliki kelayakan isi dan kualitas yang maksimal termasuk buku paket matematika siswa SMP/MTs terbitan Kemendikbud. Kenyataan lain yaitu tidak sedikit bahkan seringkali buku paket terbitan Kemendikbud mendapatkan kirtisi dari berbagai pihak, walaupun sebelumnya buku paket yang direkomendasikan oleh pemerintah tersebut telah melalui proses penelaahan oleh ahlinya (Ramda, 2017: 14).

Tertulis tentang Standar Nasional Pendidikan pada Peraturan Pemerintah Nomor 19 Tahun 2005 yang salah satunya terdapat standar isi, standar kompetensi lulusan, standar proses, standar pendidikan dan kependidikan, sarana dan prasarana, standar penilaian pendidikan, pengelolaan dan pembiayaan merupakan sarana pendidikan yang ternyata perlu diatur standar mutu pendidikannya. Terkait dengan hal tersebut, salah satu upaya yang dapat menjadi sumbangsih pemikiran yakni dengan melakukan sebuah kajian evaluasi. Hal lain diperkuat oleh temuan Bell (1978: 385) yang mengungkapkan bahwa terdapat empat kriteria yang dapat digunakan untuk mengevaluasi sebuah buku pelajaran matematika yaitu kriteria yang berhubungan dengan materi matematika, metode penyampaian materi, karakteristik fisik buku dan kriteria yang berkaitan dengan buku guru.

Sehubungan dengan hal tersebut, maka untuk mengevaluasi sebuah buku pelajaran matematika dalam hal kontennya, maka dapat menggunakan 21 kriteria yang disusun oleh Bell untuk mengevaluasi sebuah buku matematika (Fajriatin, 2017: 74), diantaranya:

1. Are the mathematics facts, concept, skills and principles correct?
2. Are standard mathematics symbols and other notation used?

3. Does the book contain a number of printing errors and incorrect answers which interfere with comprehension of the content?

4. Is the presentation of content overly symbolic and abstract?

5. Are mathematical concepts defined correctly?

6. Are the underlying structures of the mathematical systems that are presented apparent?

7. Does the book deal with the history, philosophy, and methods of mathematics and mathematicians?

8. Are the levels of rigor and precision appropriate for your students?

9. Does the book take a modern or a traditional approach to mathematical content?

10. Does the textbook emphasize mathematical facts and skill or does it emphasize concept and principles?

11. Are valid logical forms used in proving propositions?

12. Does the book emphasize proof?

13. Is problem solving considered in the book?

14. Are the proofs, explanations and examples complete and understandable for the students who will using the book?

15. As new topics are introduced, are their relationships to previous topics apparent so that the structure of mathematical systems is obvious?

16. Does the text point out common logical errors such as circular reasoning, assuming the truth of the convers of a theorem, and using unproven propositions to prove theorems?

17. Are mathematical terms defined correctly and understandable?

18. Are different meanings and uses of mathematical terms pointed out?

19. Is there a clear distinction between undefined terms, defined terms, and theorems?

20. Is a clear distinction made between a proof and a reasonable conjecture? 
21. Are all of the topics that you want to teach in the course included in the book?

Berdasarkan uraian yang telah dipaparkan, peneliti melakukan analisis berkenaan dengan buku paket matematika berdasarkan kontennya dengan judul "Analisis Konten pada Buku Paket Matematika Siswa SMP Menggunakan Kriteria Bell”. Dengan tujuan untuk menganalisis seberapa tinggi keselarasan konten pada buku paket matematika siswa SMP apabila dianalisis menggunakan kriteria Bell.

\section{METODE}

Penelitian ini termasuk penelitian dengan menggunakan metode penelitian kualitatif. Adapun pendekatan yang digunakan dalam penelitian ini adalah pendekatan deskriptif yang bertujuan untuk mengetahui keselarasan dari sisi kontennya pada buku paket matematika siswa Sekolah Menengah Pertama kelas VII semester genap edisi Kurikulum 2013 Revisi 2016 terbitan Kemendikbud menggunakan kriteria Bell. Dalam penelitian ini tidak diberikan manipulasi atau pengubah pada variabel-variabel yang diteliti, melainkan menggambarkan suatu kondisi yang apa adanya.

Prosedur penelitian dilakukan dengan tiga tahap, yaitu tahap persiapan, tahap pelaksanaan dan tahap analisis. Masing-masing tahap diuaraikan sebagai berikut.

\section{Tahap persiapan}

Kegiatan yang dilakukan pada tahap persiapan ini meliputi:

a. Menyusun instrumen meliputi lembar validasi bahasa instrumen pertanyaan untuk menganalisis konten pada buku paket matematika siswa Sekolah Menengah Pertama terbitan Kemendikbud berdasarkan kriteria Bell dan lembar analisis keselarasan konten pada buku paket matematika siswa
Sekolah Menengah Pertama terbitan Kemendikbud berdasarkan kriteria Bell.

b. Menganalisis lembar validasi bahasa instrumen pertanyaan untuk menganalisis konten pada buku paket matematika siswa Sekolah Menengah Pertama terbitan Kemendikbud berdasarkan kriteria Bell.

2. Tahap pelaksanaan

Kegiatan yang dilakukan pada tahap pelaksanaan adalah menganalisis konten pada buku paket matematika siswa Sekolah Menengah Pertama terbitan Kemendikbud berdasarkan kriteria Bell dengan teknik dokumentasi melalui angket berupa lembar analisis kesesuaian konten pada buku paket matematika siswa Sekolah Menengah Pertama terbitan Kemendikbud berdasarkan kriteria Bell.

\section{Tahap analisis}

Data yang diperoleh dalam penelitian ini dianalisis sesuai dengan teknik analisis data.

Sebelum instrumen tersebut digunakan, terlebih dahulu dikonsultasikan kepada dosen pembimbing yang kemudian dilakukan penilaian dan meminta pertimbangan kepada validator untuk mengetahui tingkat kevalidan agar dapat diputuskan apakah perlu dilakukan revisi atau tidak sebelum instrumen tersebut digunakan.

Berdasarkan penilaian yang diberikan validator, selanjutnya akan ditentukan nilai rata-rata total untuk semua kriteria $\left(V_{a}\right)$. Nilai $V_{a}$ ditentukan untuk melihat tingkat kevalidan bahasa instrument pertanyaan untuk menganalisis konten pada buku paket matematika siswa Sekolah Menengah Pertama terbitan Kemendikbud berdasarkan kriteria Bell. Adapun langkah langkah untuk penentuan nilai $V_{a}$ sebagai berikut. 
a. Menentukan nilai rata-rata hasil validasi dari semua validator untuk setiap indikator $\left(I_{i}\right)$ dengan persamaan sebagai berikut Hobri dalam Beni et al. (2013: 52-53).

$$
I_{i}=\frac{\sum_{j=1}^{v} V_{j i}}{v}
$$

Dengan:

$I_{i} \quad=$ Rerata nilai untuk indikator ke- $i$

$V_{j i}=$ Data nilai validator ke-j terhadap indikator ke- $i$

$v \quad=$ Banyaknya validator

b. Menentukan nilai rata-rata untuk setiap kriteria $\left(A_{i}\right)$ dengan menggunakan nilai $I_{i}$. Adapun persamaannya sebagai berikut Hobri dalam Beni et al. (2013: 52-53).

$$
A_{i}=\frac{\sum_{j=1}^{m} I_{j i}}{m}
$$

Dengan:

$A_{i}=$ Rerata nilai untuk kriteria ke- $i$

$I_{j i}=$ Rerata untuk kriteria ke- $i$ indikator ke- $j$

$m$ = Banyaknya indikator dalam kriteria ke$i$

c. Menentukan nilai rerata total semua indikator $\left(V_{a}\right)$ dengan persamaan sebagai berikut Hobri dalam Beni et al. (2013: 5253).

$$
V_{a}=\frac{\sum_{i=1}^{n} I_{i}}{n}
$$

Dengan:

$V_{a}=$ Nilai rata-rata total semua indikator

$I_{i}=$ Rata-rata nilai untuk indikator ke- $i$

$n=$ Banayaknya indikator

Selanjutnya, nilai atau rata-rata total untuk semua indikator $\left(V_{a}\right)$ diberikan kategori untuk menentukan tingkat kevalidan instrument, yang dikategorikan pada Tabel 1.

Tabel 1. Tingkat Kevalidan Instrumen

\begin{tabular}{cc}
\hline Nilai $\boldsymbol{V}_{\boldsymbol{a}}$ & Tingkat Kevalidan \\
\hline $3,4 \leq V_{a} \leq 4$ & Sangat Valid \\
\hline
\end{tabular}

\begin{tabular}{cc}
\hline $2,8 \leq V_{a}<3,4$ & Valid \\
\hline $2,2 \leq V_{a}<2,8$ & Cukup valid \\
\hline $1,6 \leq V_{a}<2,2$ & Kurang Valid \\
\hline $1 \leq V_{a}<1,6$ & Tidak Valid \\
\hline
\end{tabular}

Sumber : Dimodifikasi dari Hobri dalam (Beni et al., 2013)

Setiap tingkat kevalidan tersebut memiliki ketentuan yang tertera pada Tabel 2.

Tabel 2. Ketentuan Tingkat Kevalidan Instrumen

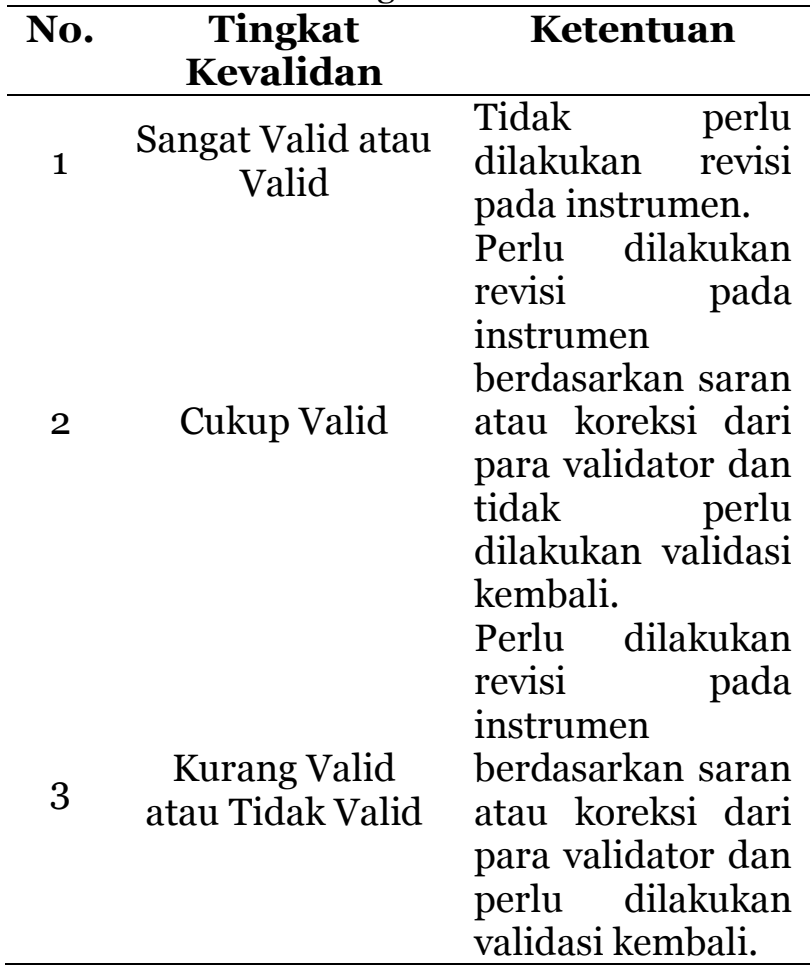

Adapun cara menganalisis data penelitian, dapat dilakukan dengan tiga jenis langkah sebagai berikut.

\section{Langkah 1: Analisis konten pada buku paket matematika siswa}

Langkah pertama, isi materi pada buku paket matematika siswa dianalisis dengan cara memperhatikan konteks pada konten buku paket matematika siswa yang kemudian disesuaikan dengan indikator-indikator daripada konten kriteria Bell.

\section{Langkah 2: Argumentasi dan kesimpulan}


Argumentasi ini didasarkan pada informasi yang terkumpul pada langkah pertama yang telah disesuaikan dengan indikator-indikator dari konten kriteria Bell untuk memberikan penilaian terhadap analisis kesesuaian konten pada buku paket matematika siswa Sekolah Menengah Pertama kelas VII semester genap terbitan Kemendikbud berdasarkan kriteria Bell. Kesimpulan ini dimaksudkan untuk memberikan pengelompokan indikator berdasarkan data hasil analisis dan argumentasi yang sudah dibuat.

\section{Langkah 3: Analisis Kuantitatif}

Sebagai langkah terakhir, setiap indikator yang telah dianalisis dengan memenuhi langkah 1 dan langkah 2 kemudian secara kuantitatif dianalisis untuk mengukur kesesuaian konten pada buku paket matematika siswa SMP kelas VII semester genap terbitan Kemendikbud berdasarkan kriteria Bell yang didapatkan menggunakan instrumen check-list yang kemudian data tersebut diukur persentase nya dengan perhitungan yang disajikan dalam persamaan sebagai berikut Arikunto (2013: 266).

$$
p=\frac{q}{q_{c}} \times 100 \%
$$

Dengan:

$p=$ Persentase kesesuaian buku

$q$ = Jumlah pertanyaan yang sesuai

$q_{c}=$ Banyak pertanyaan per kriteria

Adapun persentase kesesuaian buku ditunjukkan pada Tabel 3 .

Tabel 3. Kategori Persentase Kesesuaian Buku

\begin{tabular}{cc}
\hline $\begin{array}{c}\text { Persentase } \\
\text { Kesesuaian }\end{array}$ & Kategori \\
\hline $80 \%<p \leq 100 \%$ & Sangat Baik \\
$60 \%<p \leq 80 \%$ & Baik \\
$40 \%<p \leq 60 \%$ & Cukup \\
$20 \%<p \leq 40 \%$ & Kurang \\
$P \leq 20 \%$ & Sangat Kurang \\
\hline
\end{tabular}

Sumber : Asih dalam (Beni et al., 2013: 54)

\section{HASIL DAN PEMBAHASAN}

Buku paket matematika yang menjadi sumber rujukan pada penelitian ini berjudul "Matematika - Studi dan Pengajaran". Buku paket ini terdiri dari lima bab yaitu memuat bab Perbandingan, Aritmetika Sosial, Garis dan Sudut, Segiempat dan Segitiga dan Penyajian Data. Adapun identitas buku paket matematika tersebut secara ringkas sebagai berikut.

$$
\begin{aligned}
& \text { Judul : Matematika - Studi dan } \\
& \text { Buku : Pengajaran. } \\
& \text { Abdur Rahman As'ari, } \\
& \text { Penulis : Mohammad Tohir, Erik } \\
& \text { Valentino, Zainul Imron dan } \\
& \text { Ibnu Taufiq. } \\
& \text { Agung Lukito, Ali Mahmudi, } \\
& \text { Penelaah : Turmudi, M., Nanang } \\
& \text { Widowati. } \\
& \text { Penyelia Pusat Kurikulum dan } \\
& \text { Penerbit : Perbukuan, Balibang, } \\
& \text { Kemdikbud. }
\end{aligned}
$$

Hasil kesesuaian konten pada buku paket matematika siswa SMP kelas VII semester genap terbitan Kemendikbud berdasarkan kriteria Bell pada bab Perbandingan indikator yang terpenuhi adalah indikator nomor 1, 2, 5, $6,7,8,9,10,13,14,15,17,18,19$, dan 21. Persentase kesesuaian pada bab Perbandingan sebesar $71,43 \%$.

Fakta merupakan kesepakatan atau ketentuan dalam matematika. Simbol matematika termasuk kedalam fakta, misalkan " 6 " dalam bahasa Indonesia dibaca "enam" kemudian "\%" dalam bahasa Indonesia dibaca "persen" (Haustin, 2014: 13). Fakta yang tersajikan dalam bab perbandingan pada buku paket matematika siswa Sekolah Menengah Pertama kelas VII semester genap edisi Kurikulum 2013 Revisi 2016 terbitan Kemendikbud diantaranya terdapat fakta mengenai pebandingan senilai yaitu: $y=k x$, jika $x$ meningkat maka $y$ meningkat. Kemudian terdapat fakta mengenai persamaan perbandingan berbalik nilai yaitu $y$ 
$=\frac{k}{x}$,jika $x$ meningkat maka $y$ meningkat, selain hal tersebut terdapat pula persamaan untuk menentukan skala peta dengan menggunakan konsep perbandingan. Salah satu contoh yang menunjukkan fakta pada bab perbandingan dapat dilihat pada Gambar 1.

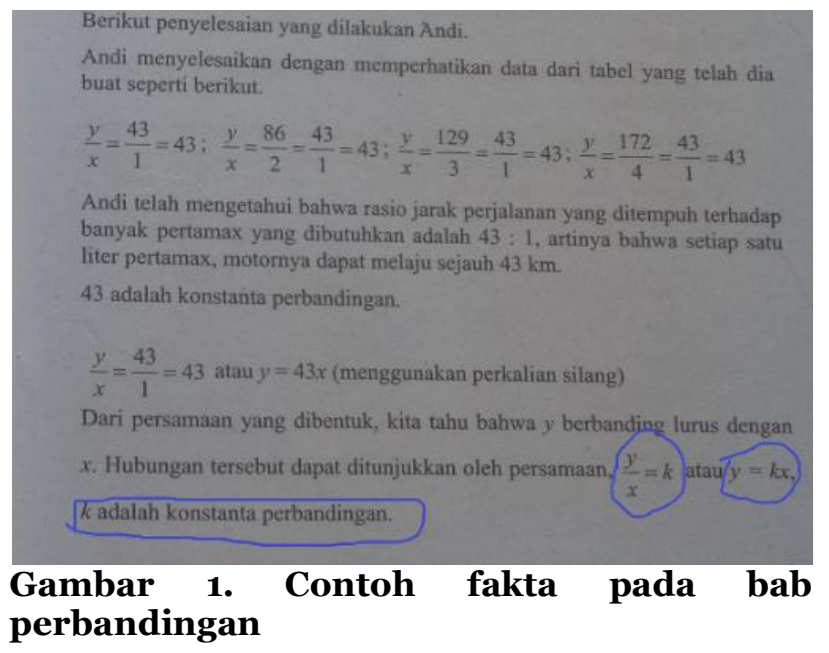

Wardhani (2010: 4) mengungkapkan apabila seseorang mengelompokkan atau menggolongkan suatu objek, yang mana objek tersebut termasuk contoh konsep atau bukan konsep maka hal tersebut dinamakan konsep. Contoh: $x>y$ merupakan konsep, sebab kita dapat menyebutkan fakta misalkan $6>4$.

Pada bab perbandingan konsep-konsep disajikan melalui peristiwa yang sering dijumpai pada kehidupan sehari-hari seperti melalui media foto keluarga untuk memperoleh informasi perbandingan banyak laki-laki dengan perempuan. Selain hal tersebut, konsep pada bab perbandingan disajikan dengan berupa label informasi nilai gizi pada suatu bungkus biskuit, terdapat pula hal mengamati tabel situasi perbandingan senilai, mengamati gambar peta provinsi Kalimantan Timur untuk membandingkan antara gambar dengan keadaan sebenarnya. Adapun contoh konsep yang tersajikan pada bab perbandingan dapat dilihat pada Gambar 2.

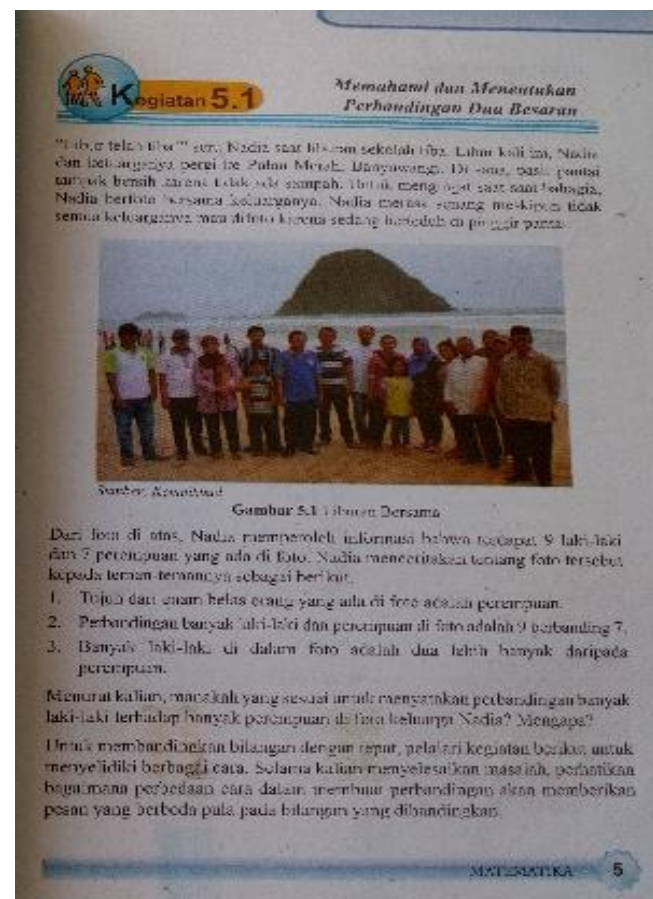

Gambar 2. Contoh konsep pada bab perbandingan

Keterampilan dalam matematika yaitu operasi dan prosedur yang diharapkan dapat menyelesaikan soal matematika dengan cepat dan tepat (Azizah, 2015: 16). Misalnya, menjumlahkan $\sin \propto$ dengan $\sin \propto$, mengalikan $\cos \propto$ dengan $\cos \propto$. Terdapat beberapa keterampilan yang tersajikan pada bab perbandingan diantaranya keterampilan menyatakan suatu rasio dan menentukan skala peta. Contoh keterampilan pada bab perbandingan dapat dilihat pada Gambar 3 .

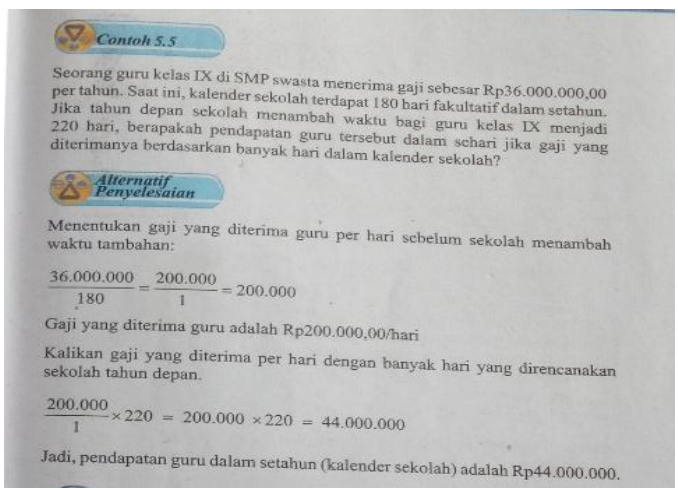

Gambar 3. Contoh keterampilan pada bab perbandingan 
Wardhani (2010: 5) menyatakan bahwa prinsip adalah hubungan antara beberapa fakta dan konsep yang dikaitkan dengan suatu operasi. Prinsip dapat berupa aksioma, teorema dan lain-lain. Contoh prinsip yaitu luas persegi panjang adalah hasil kali dari panjang dan lebarnya, pernyataan tersebut merupakan contoh prinsip. Prinsip yang tersajikan pada bab perbandingan diantaranya adalah mengenai cara menentukan skala peta, menentukan kecepatan dan waktu tempuh. Contoh prinsip pada bab perbandingan dapat dilihat pada Gambar 4.
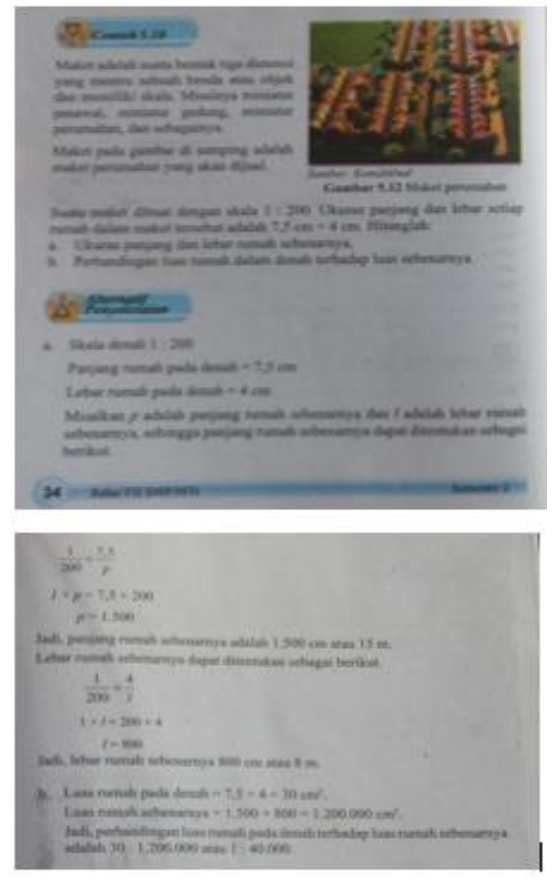

Gambar 4. Contoh prinsip pada bab
perbandingan

Sedangkan indikator yang tidak terpenuhi pada bab perbandingan memuat indikator nomor 3, 4, 11, 12, 16 dan 20. Indikator nomor 3 membahas mengenai isi buku terkait kesalahan (tulisan) yang salah cetak dan jawaban yang salah yang mempengaruhi pemahaman terhadap isi buku. Pada bab perbandingan ini memang terdapat beberapa kesalahan (tulisan) yang salah cetak, akan tetapi tidak mempengaruhi pemahaman terhadap isi buku. Diantara kesalahan yang salah cetak tersebut antara lain yaitu terdapat tulisan dengan yang dimaksudkan pada cake yang berarti kue, tetapi pada buku tersajikan cara penulisan yang tidak sesuai dengan kaidah bahasa Indonesia. Tentu hal tersebut bukan faktor yang dapat mempengaruhi pemahaman isi buku. Selanjutnya terdapat kata 'alian' yang seharusnya menunjukkan kata 'kalian'. Adapun contoh yang menujukkan terdapat kesalahan (tulisan) yang salah cetak dapat dilihat pada Gambar 5 .

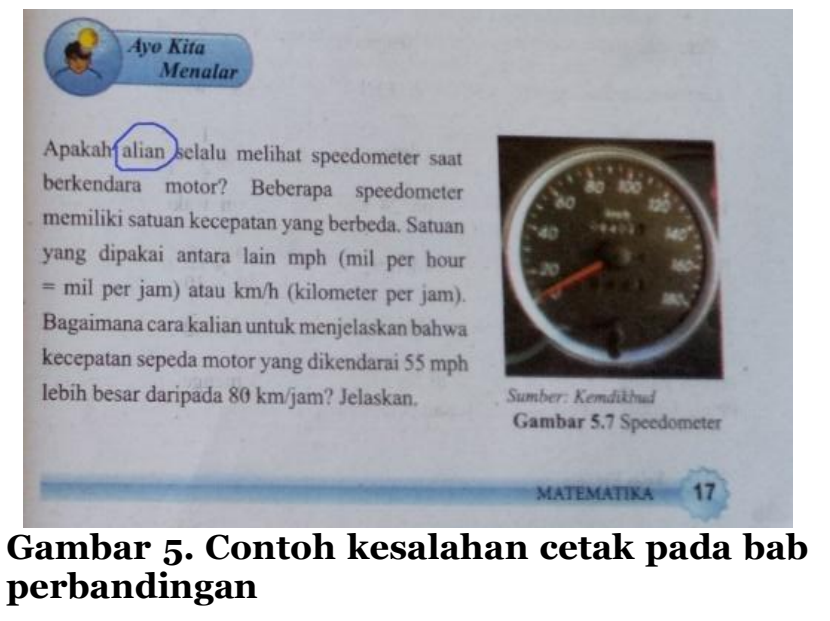

Hasil kesesuaian konten pada buku paket matematika siswa SMP kelas VII semester genap terbitan Kemendikbud berdasarkan kriteria Bell pada bab Aritmetika Sosial indikator yang terpenuhi adalah indikator nomor 1, 2, 5, 6, 7, 9, 10, 13, 14, 15, 17, 18, 19 dan 21. Persentase kesesuaian pada bab Aritmetika Sosial sebesar 66, 67\%. Simbol matematika yang berlaku adalah simbol secara internasional. Haustin (2014: 14) mengemukakan bahwa suatu operasi, besaran dan lainnya seperti $\neq, \sqrt{ },+,=$ dan lainnya merupakana tanda untuk menyatakan simbol. Sedangkan dalam KBBI (2014: 621) notasi merupakan sebuah lambang (tanda) yang menggambarkan bilangan. Adapun contoh notasi yaitu // sebagai notasi dari kesejajaran dan lain sebagainya. Simbol yang digunakan pada bab aritmetika sosial mencakup perkalian $(\times)$, pengurangan $(-)$, pembagian (/), sama dengan $(=)$. Contoh yang menunjukkan bahwa 
pada bab aritmetika sosial terdapat simbol yang digunakan dapat dilihat pada Gambar 6.

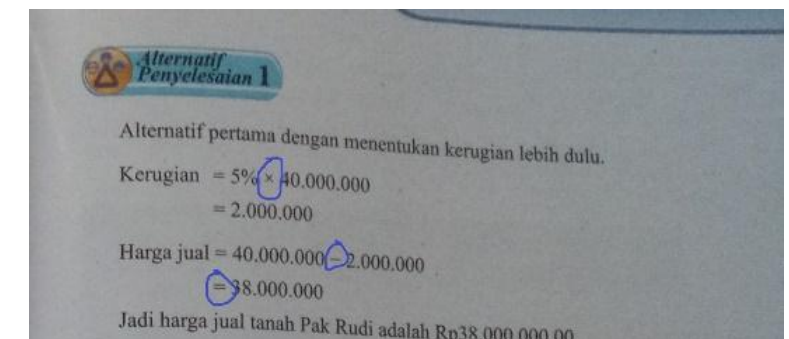

Gambar 6. Contoh simbol yang digunakan pada bab aritmetika sosial

Kemudian notasi yang digunakan pada bab aritmetika sosial diantaranya adalah persen (\%), tentu simbol persen ini digunakan pada bab aritmetika sosial untuk menunjukkan persentase karena pada bab aritmetika sosial terdapat beberapa pembahasan mengenai persentase. Berikut contoh notasi matematika yang terdapat pada bab aritmetika sosial.

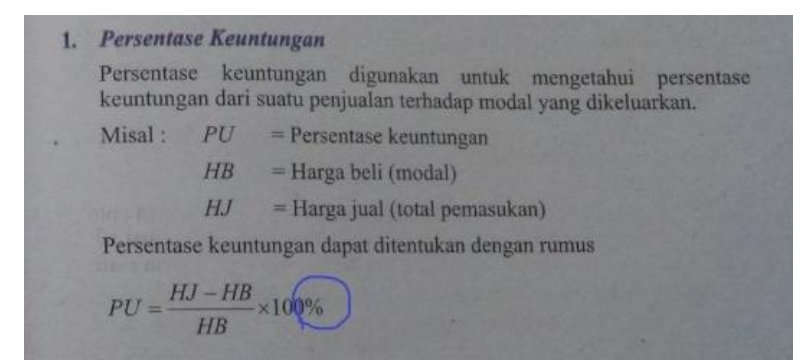

Gambar 7. Contoh notasi yang digunakan pada bab aritmetika sosial

Sedangkan indikator yang tidak terpenuhi pada bab aritmetika sosial mencakup indikator nomor 3, 4, 8, 11, 12, 16 dan 20. Pada indikator nomor 4 membahas mengenai penyajian isi buku terlalu simbol dan abstrak, tentu pada bab atirmetika sosial isi buku disajikan tidak terlalu simbolik dan tidak abstrak. Hal tersebut dikarenakan isi buku dideskripsikan dengan jelas berkaitan dengan kehidupana sehari-hari, soal-soal yang tersajikan pun dalam bentuk cerita. Pada Gambar 8 tersajikan contoh isi buku pada bab aritmetika sosial yang menunjukkan bahwa isi buku tidak terlalu simbolik dan tidak abstrak.
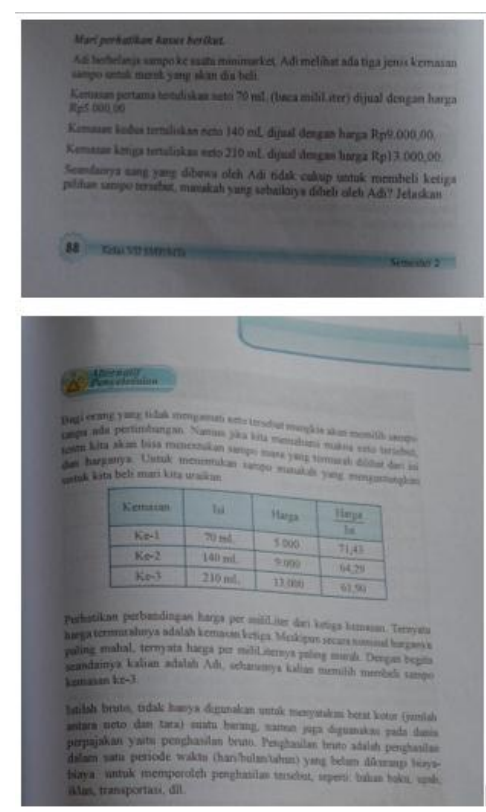

Gambar 8. Contoh penyajian isi buku yang tidak terlalu simbolik dan tidak abstrak pada bab aritmetika sosial

Adapun hasil konten pada buku paket matematika siswa SMP kelas VII semester genap terbitan Kemendikbud berdasarkan kriteria Bell pada bab Garis dan Sudut, indikator yang terpenuhi adalah indikator nomor 1, 2, 3, 5, 6, 7, 8, 9, 10, 13, 14, 15, 17, 18, 19 dan 21. Persentase kesesuaian pada bab Garis dan Sudut sebesar 76, 20\%.

Fajriatin (2017: 10-11) mengungkapkan bahwa untuk dapat membantu seseorang membuat ilustrasi atau gambar dari konsep yang telah didefinisikan supaya jelas maksud dari konsep tersebut, maka hal tersebut dinamakan definisi. Misalnya adalah "Refleksi (pencerminan) adalah termasuk jenis transformasi yang mana dengan bantuan sifat benda dan bayangannya pada cermin yang datar yang dapat memindahkan tiap titik dari suatu bidang atau bangun geometri”. Terdapat konsep-konsep matematika yang didefinisikan dengan benar pada bab garis dan sudut, diantara konsepkonsep matematika yang didefinisikan tersebut adalah konsep titik, garis, bidang datar, titiktitik segaris, titik-titik sebidang dan sudut. 
Contoh bahwa pada bab garis dan sudut tersajikan konsep-konsep matematika yang didefinisikan dengan benar dapat dilihat pada Gambar 9.

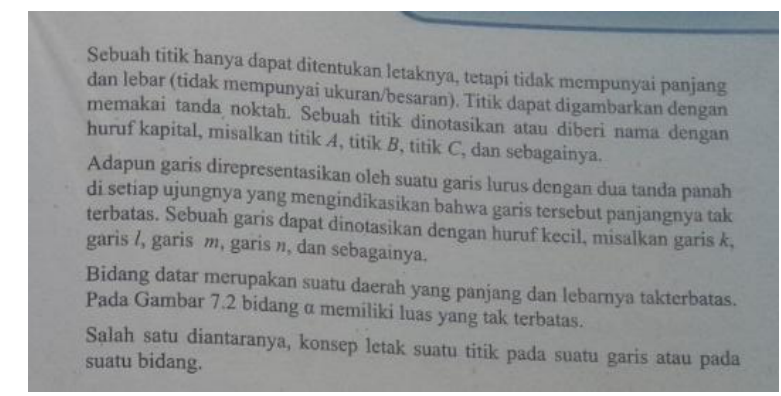

Gambar 9. Contoh konsep matematika yang didefinisikan dengan benar pada bab garis dan sudut

Indikator yang tidak terpenuhi pada bab garis dan sudut memuat indikator nomor 4, 11, 12, 16 dan 20. Kesesuaian konten pada buku paket matematika siswa SMP kelas VII semester genap terbitan Kemendikbud berdasarkan kriteria Bell pada bab Segiempat dan Segitiga, indikator yang terpenuhi adalah indikator nomor $1,2,3,5,6,7,9,10,12,13,15,16,17,18$, 19, 20 dan 21. Persentase kesesuaian buku pada bab Segiempat dan Segitiga sebesar 80, 95\%. Lestari (2011: 4) mengemukakan bahwa abstrak merupakan ciri yang menunjukkan suatu benda yang tidak konkret atau tidak berwujud. Pada umumnya, konsep matematika adalah abstrak, contoh konsep yang abstrak adalah bilangan, garis-garis dan garis-garis bilangan. Penggunaan simbol yang terlalu banyak dalam mengungkapkan sebuah ide dalam menyajikan sebuah materi merupakan contoh dari isi yang terlalu simbolik dan abstrak. Apabila sebuah buku menyajikan materi terlalu simbolik dan abstrak, hal tersebut dapat membuat siswa kurang dapat mencerna maksud yang dituju. Penyajian isi buku pada bab segiempat dan segitiga tidak terlalu simbolik dan tidak abstrak, hal tersebut karena dijelaskannya atau terdapat hal yang menunjukkan akan suatu maksud tertentu. Contoh yang menunjukkan bahwa pada bab segiempat dan segitiga tidak terlalu simbolik dan tidak abstrak dapat dilihat pada Gambar 10.

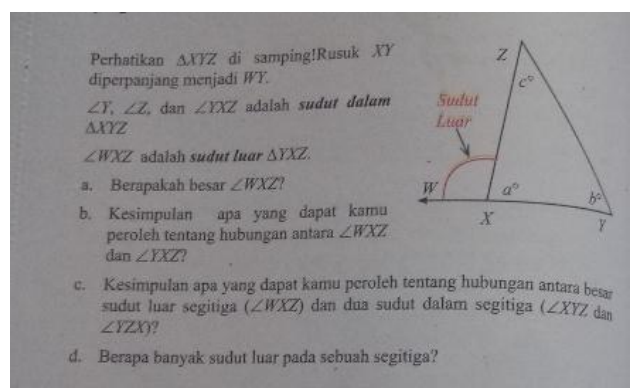

Gambar 10. Contoh penyajian isi buku tidak terlalu simbolik dan abstrak pada bab segiempat dan segitiga

Indikator yang tidak terpenuhi pada bab segiempat dan segitiga memuat indikator nomor 4, 8, 11 dan 14. Untuk indikator nomor 14 membahas mengenai bukti-bukti, penjelasanpenjelasan dan contoh-contoh tersaji lengkap dan dapat dimengerti oleh siswa yang akan menggunakan buku, pada bab segiempat dan segitiga terjadi kesalahan logika sebuah pembuktian yang membuat kesalahpahaman pemikiran, maka sebagai pembaca terlebih siswa mengalami kesulitan untuk memahaminya. Maka dengan hal tersebut peran guru dalam menyaring informasi yang tersajikan dalam buku harus berhati-hati guna menghilangkan ketidakpahaman yang tersajikan dalam buku. Berikut contoh pada bab segiempat dan segitiga yang terdapat kesalahan pada pembuktian yang mengganggu pemahaman isi buku dan siswa yang menggunakan buku tersebut.

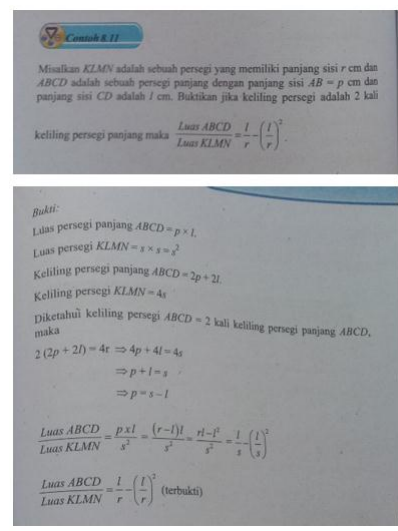

Gambar 11. Contoh pembuktian yang dapat terjadi kesalahan pemahaman pada siswa dalam bab segiempat dan segitiga 
Adapun kesesuaian buku paket matematika siswa Sekolah Menengah Pertama edisi Kurikulum 2013 revisi 20116 terbitan Kemendikbud berdasarkana konten kriteria Bell pada bab Penyajian Data, indikator yang terpenuhi adalah indikator nomor 1, 2, 3, 5, 6, 7, 8, 9, 10, 13, 14, 15, 17, 18, 19 dan 21. Persentase kesesuaian buku pada bab Penyajian Data sebesar 76, 20\%.

Menurut KBBI (2014: 812) struktur yaitu cara bagaimana sesuatu disusun. Dalam struktur matematika yang lengkap terdapat aksiomaaksioma, konsep-konsep yang didefinisikan, teorema-teorema, lemma, corollary dan lain sebagainya. Struktur dasar sistem matematika yang tersajikan pada bab penyajian data berupa konsep-konsep yang didefinisikan diantaranya terdapat definisi konsep mengenai data, data primer, data sekunder, diagram lingkaran, diagram batang dan diagram garis. Contoh struktur dasar sistem matematika yang terdapat pada bab penyajian data dapat dilihat pada Gambar 12.

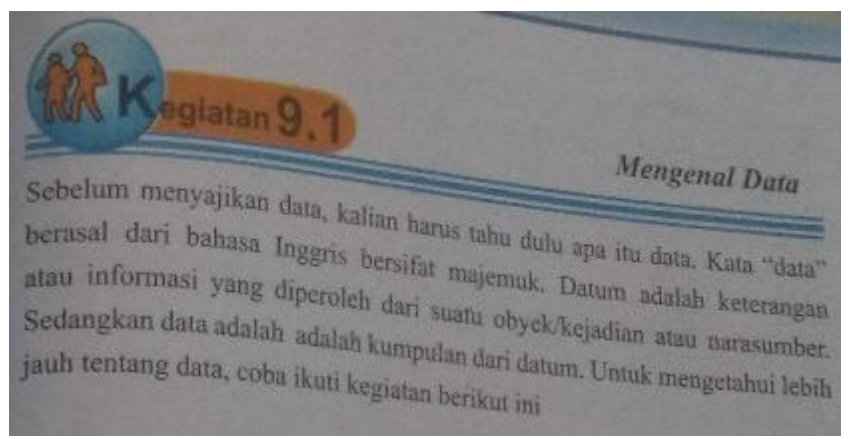

Gambar 12. Contoh struktur dasar sistem matematika yang terdapat pada bab penyajian data

Indikator yang tidak memenuhi mencakup indikator nomor 4, 11, 12, 16 dan 20. Hasil rekap keselarasan konten pada buku paket matematika siswa SMP kelas VII terbitan Kemendikbud berdasarkan kriteria Bell tersajikan pada Tabel 4 .
Tabel 4. Rata-rata persentase kesesuaian konten pada buku paket matematika siswa SMP kelas VII terbitan Kemendikbud berdasarkan kriteria Bell secara keseluruhan

\begin{tabular}{clc}
\hline No. & \multicolumn{1}{c}{ BAB } & Persentase \\
\hline 1 & 5 (Perbandingan) & $71,43 \%$ \\
2 & 6 (Aritmetika Sosial) & $66,67 \%$ \\
3 & 7 (Garis dan Sudut) & $76,20 \%$ \\
4 & $8 \quad$ (Segiempat dan & $80,95 \%$ \\
& Segitiga) & $76, \mathbf{2 0} \%$ \\
5 & 9 (Penyajian Data) & $\mathbf{7 4 , 2 9 \%}$ \\
Rata-rata persentase
\end{tabular}

Berdasarkan hasil analisis konten pada buku paket matematika siswa SMP dengan menggunakan kriteria Bell tersebut mencapai kategori baik, hal-hal yang menyebabkan buku paket matematika tersebut mencapai kategori baik adalah karena materi pada semester genap ini tidak semua bab mencakup sebuah pembuktian dan hanya terdapat satu pembuktian yang tersajikan pada bab segiempat dan segitiga yang mana pada pembuktian tersebut juga terjadi kekeliruan dengan tidak konsistennya pada pemberian pemisalan. Selain hal tersebut, pada bab Segiempat dan Segitiga pun diketahui terdapat kesalahan logika pada pembuktian sebuah dalil, selain dari itu terdapat kesalahan cetak (tulisan) yang dapat mempengaruhi pemahaman terhadap isi buku.

\section{KESIMPULAN}

Berdasarkan hasil analisis data mengenai buku paket matematika siswa SMP kelas VII semester genap edisi Kurikulum 2013 Revisi 2016 terbitan Kemendikbud yang peneliti lakukan, secara garis besar dapat disimpulkan bahwa konten pada buku paket matematika siswa SMP kelas VII terbitan Kemendikbud berdasarkan kriteria Bell pada bab perbandingan mencapai $71,43 \%$, sedangkan pada bab aritmetika sosial mencapai 66, 67\%, kemudian pada bab garis dan sudut mencapai kesesuaian 76, 205, bab segiempat dan segitiga mencapai 80, 95\% dan pada bab penyajian data kesesuaian mencapai 76, 20\%. Adapun rata-rata persentase keselarasan konten pada buku paket matematika siswa SMP kelas VII terbitan 
Kemendikbud berdasarkan kriteria Bell secara keseluruhan mencapai $74,29 \%$ yang mana kesesuaian buku termasuk pada kategori baik. Adapun yang menyebabkan keselarasan konten pada buku paket matematika siswa tersebut tidak mencapai 100\% menggunakan kriteria Bell adalah karena pada bab perbandingan, aritmetika sosial, garis dan sudut dan bab penyajian data tidak terdapat pembuktian sebuah dalil dan sebuah teorema. Selain hal tersebut pada bab segiempat dan segitiga pun diketahui terdapat kesalahan logika pada pembuktian sebuah dalil, selain dari itu terdapat kesalahan cetak (tulisan) yang dapat mempengaruhi pemahaman terhadap isi buku.

\section{REFERENSI}

Arikunto, Prof. Dr. S. (2013). Manajemen penelitian. Rineka Cipta.

Azizah, R. (2015). Analisis buku teks matematika kurikulum 2013 penerbit kementerian pendidikan dan kebudayaan untuk SMA kelas XI pokok bahasan statistika berdasarkan kriteria bell.

Bell, F. H. (1978). Teaching and learning mathematics (in secondary schools). Wm. C. Brown Company Publisher.

Beni, I. G., Trapsilasiwi, D., \& Kristiani, A. I. (2013). Analisis buku matematics for junior high school grade VIII 1 st semester (bilingual) berdasarkan kriteria bell. KadikmA, 4(2).

Fajriatin, A. (2017). Analisis buku matematika kelas IX kurikulum 2013 berdasarkan kesesuaiannya dengan materi matematika menurut kriteria bell dan pendekatan saintifik. PROSIDING, 67.

Haustin, Z. H. (2014). Analisis buku matematika SMP/MTs kelas VII semester $i$ kurikulum 2013 berdasarkan kriteria bell.

Ikhwandi, I., Dafik, D., \& Suciati, S. (2015). Telaah kesesuaian buku guru matematika kelas X kurikulum 2013 berdasarkan pendekatan saintifik. Pancaran Pendidikan, 4(1), 117-128.

KBBI, K. B. B. I. (2014). Kamus bahasa indonesia edisi terbaru. Pandom Media Nusantara.

Lestari, Y. P. (2011). Ensiklopedia matematika $(A-J)$. PT INDAHJAYA Adipratama.

Ramda, A. H. (2017). Analisis kesesuaian materi buku teks Kemendikbud matematika kelas VII dengan Kurikulum 2013. Pythagoras: Jurnal Pendidikan Matematika, 12(1), 12-22.

Shield, M., \& Dole, S. (2013). Assessing the potential of mathematics textbooks to promote deep learning. Educational Studies in Mathematics, 82(2), 183199.

Wardhani, S. (2010). Implikasi karakteristik matematika dalam pencapaian tujuan mata pelajaran matematika di SMP/MTs. Departemen Pendidikan Nasional Direktorat Jenderal Peningkatan Mutu Pendidik Dan Tenaga Kependidikan Pusat Pengembangan Dan Pemberdayaan Pendidik Dan Tenaga Kependidikan (PPPPTK) Matematika. 